\title{
The use of natural cold in the processing and storage of food in the extreme conditions of Yakutia
}

\begin{abstract}
A. F. Abramov Sciences, Yakutsk, The Russian Federation; yniicx@mail.ru

Received May 2013
\end{abstract}

The State Scientific Institution, The Yakut Scientific Research Institute of Agriculture, The Russian Academy of Agricultural

Keywords: Natural Cold; Technologies; Patents; Regulations

\section{INTRODUCTION}

Justification for the use of natural cold in the processing and storage of foods is discussed. In the Far North, including Yakutia, in the past centuries, the local population traditionally widely used freezing and stored food by natural cold. At present, despite the high efficiency of natural cold in the processing and storage of food in the Far North, it is rarely used in industrial production technology, processing and storage of products. The main reason has been the widespread use of artificial cold. However, the high cost of electricity, equipment and refrigerants requires more in-depth and extensive research on the development of advanced technologies and equipment for the preservation and storage of natural cold food in the extreme conditions of the North.

Expected efficiency:

- Energy savings of $40 \%-50 \%$ in the period of processing and storage as compared to using artificial cold;

- Environmental friendliness of natural cold;

- Minimum weight loss of products;

- The products are stored in bulk form without the use of preservatives;

- High degree of conservation of taste and nutritional products.

\section{THE MAIN SOURCES OF NATURAL COLD}

In Yakutia the main sources of natural cold are: winter cold, cold of permafrost soils and the cold accumulated in the glaciers.

Low temperatures in winter in Yakutia are the major source of cold, sometimes in winter the temperatures reach to $-55^{\circ} \mathrm{C}--60^{\circ} \mathrm{C}$. The total duration of the cold period with temperatures below $-25^{\circ} \mathrm{C}$ in the Arctic and North-Eastern areas is 150 - 160 days (from November to March), in Central Yakutia-150 - 160 days (from November to March), in Western Yakutia-90 days (from December to February), in South Yakutia-60 days (from January to February). Production of frozen foods using natural cold can begin when the night temperature reaches below $-25^{\circ} \mathrm{C}--30^{\circ} \mathrm{C}$, (Table 1).

Permafrost soils. The entire territory of the republic is occupied by permafrost, which accumulated a huge stock of cold. Power of permafrost in the country ranges from $15 \mathrm{~m}$ to $500 \mathrm{~m}$ or more (Figure 1).

\section{BIOCHEMICAL BASIS OF USING THE NATURAL COLD ON THE QUALITY OF FROZEN PRODUCT}

Many scientists and researchers on the meat industry and biochemists have proved the benefit-phase rapid freezing of meat and fish products at the temperature of $-30^{\circ} \mathrm{C}$ $--40^{\circ} \mathrm{C}$ without pre-cooling of meat and fish. They found that freezing at this temperature the cell structure in these products is not damaged due to the formation of small ice crystals, not only in the intercellular spaces, but also in the cells themselves. As a result, during defrostation of a frozen meat and fish products the losses are minimal, and they retain the primary structure, lose less juice, kept packaging and nutritional quality of fresh products.

In the Far North, including Yakutia, autumn and winter slaughter of deer, cattle, horses, when the cold temperature reaches $-25^{\circ} \mathrm{C}--30^{\circ} \mathrm{C}$, winter ice fishing has been practiced since ancient times, and in the winter months. At this temperature, there is a rapid freezing of meat and fish, equivalent to a single-phase frozen meat and fish products, where food quality is fully preserved.

According to the results of our studies, the production of frozen potatoes, vegetables, fruit, meat, dairy and fish products is practically conserved quality of fresh prod- 
Table 1. Dynamics of air temperature in the Republic of Sakha (Yakutia).

\begin{tabular}{ccccc}
\hline \multirow{2}{*}{ Months } & \multicolumn{5}{c}{ Monthly Averaged Air Temperature, $\mathrm{t}^{\circ} \mathrm{C}$} \\
\cline { 2 - 5 } & in the Arctic and North-Eastern Areas & in Central Yakutia & in Western Yakutia & in South Yakutia \\
\hline I & -41.6 & -47.1 & -32.5 & -31.4 \\
II & -38.7 & -41.7 & -31.0 & -29.4 \\
III & -33.2 & -29.8 & -15.0 & -13.1 \\
IV & -22.6 & -14.8 & -10.7 & -5.1 \\
V & -6.6 & -2.1 & +5.1 & +5.5 \\
VI & +5.6 & +10.1 & +14.1 & +13.0 \\
VII & +8.8 & +13.6 & +18.1 & +16.7 \\
VIII & +5.4 & +11.2 & +11.5 & +15.0 \\
IX & -0.6 & -0.5 & +9.9 & +10.8 \\
X & -14.1 & -18.8 & -8.5 & -3.1 \\
XI & -30.2 & -42.5 & -18.5 & -15.1 \\
XII & -49.5 & -49.5 & -29.9 & -22.5 \\
\hline
\end{tabular}

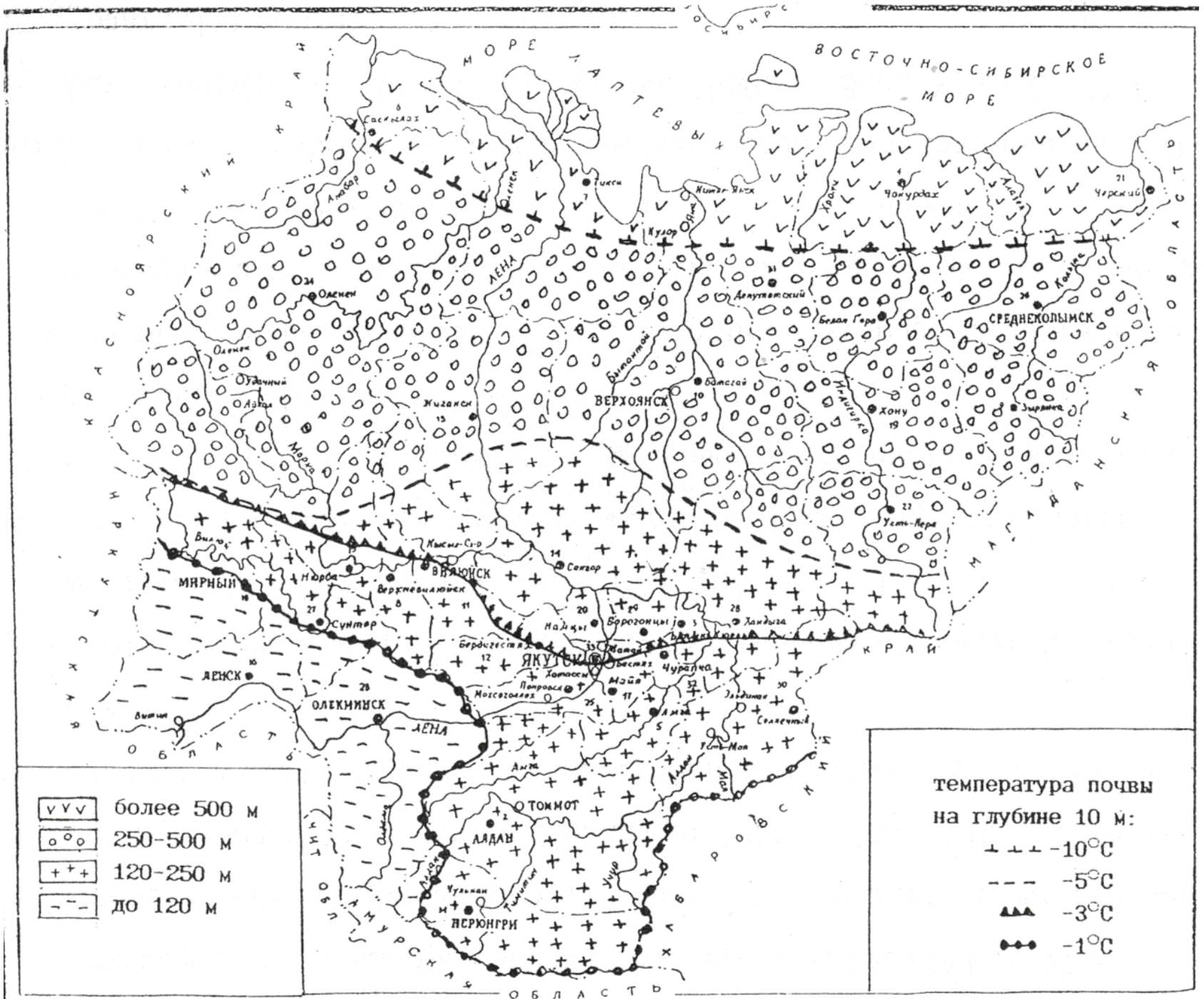

Figure 1. Map of permafrost. 
ucts in the process of rapid freezing. Major changes have occurred in the process of further storage, depending on the terms and conditions of storage of frozen products.
Originality and competition of research are protected by the following patents of the Russian Federation and regulations:

The list of technical conditions and received patents by RF for inventions on the use of natural cold for processing and storage.

\begin{tabular}{ccc}
\hline Description of works & Output data & Authors \\
\hline & Patents
\end{tabular}

Preservation method of mare's milk with cold

Refrigerator with cold outside air for the Far North regions

Winter cold fridge-battery

Winter cold fridge-battery

Method for processing potatoes

Method of freezing potatoes and vegetables

Quick-freezing machine for freezing bulk, crushed and small sized food

Method of production of low fat butter "Yakut hayah"

Washing machine for small batches of potatoes and vegetables

Method of freezing potatoes with natural cold

The receiving bin-dryer for potato

\section{Technical conditions}

Yakut hayah

TУ 9222-006-00670207-02. Date of implementation 15 of March 2004.

2344251 Russian Federation: E04H 5/10 (2006.01), F25D (2006/01)/applicant and patentee The Yakut Scientific Research Institute of Agriculture - № 2007106303/03; stated 19.02.07; published 20.01.09, bulletin № 2 .

2272415 Russian Federation: A23C 3/04/applicant and patentee The Yakut Scientific Research

Abramov A.F

2285391 Russian Federation: A01J 9/04, J25D 1/00, F25D 3/00/applicant and patentee The Yakut Scientific Research Institute of Agriculture - № 2004137065/12; stated 17.12.2004; published 20.10.2006, bulletin № 29 .

2201565 Russian Federation/applicant and patentee The Yakut Scientific Research Institute of Agriculture - № 2000127365; stated 21.10.00; published 27.03.2003

2170516 Russian Federation: 7 A 23 B 7/04, A 23 N 7/02/applicant and patentee The Yakut Scientific Abramov A.F. Research Institute of Agriculture - № 98107504/13; stated 21.04.98; published 20.07.01, bulletin № 20.Korobitzyn R.I.

2153807 Russian Federation/applicant and patentee The Yakut Scientific Research Institute of Agriculture - № 98101959/13; stated 06.02.98; published 10.08.00, bulletin № 22 .

2239134 Russian Federation/applicant and patentee The Yakut Scientific Research Institute of Agriculture - № 2003113997; stated 12.05.03; published 27.11.04.

2266009 Russian Federation: A 23 C 15/16/applicant and patentee The Yakut Scientific Research Institute of Agriculture - № 2003113996/13; stated 12.05.03; published 20.02.05, bulletin № 25 .

2284136 Russian Federation: A23N 12/02/applicant and patentee The Yakut Scientific Research Institute of Agriculture - № 2004139169/13; stated 31.12.04; published 27.09.06, bulletin № 27.

2118092 Russian Federation: 6 A 23 B 7/04, A 01 F 25/00/applicant and patentee The Yakut Scientific Korobitzyn R.I. Research Institute of Agriculture - № 96111378/13; stated 05.06.96; published 27.08.98, bulletin № 24.Abramov A.F.

2395192 Russian Federation/applicant and patentee The Yakut Scientific Research Institute of Agriculture - № 2008139724/12; stated 06.10.08; published 27.07.10, bulletin № 21.

Sozonov N.K. Abramov A.F.

Abramov A.F. Efimova A.A

National semifinished products of meat and horse foals

TУ 921400-001-44075281-00 Date of implementation 28 December 2000.

Abramov A.F.

Prokopyeva T.V.

TУ 9267-018-00670203-2007. Date of implementation 12.05.2007.

Frozen fish waste (from freshwater fish of Yakutia)

The potato frozen by the natural cold

TУ 9166-001-00670203-2002. Date of implementation 02.07.2002.

Abramov A.F.

Filippov G.G.

Abramov A.F

Abramov A.F.

Stepanov K.M.

Eliseyeva L.I.

Pavlova A.I

TУ 9222-010-00670203-2004. Date of implementation 13.09.2004.

Grigoryev I.N

Abramov A.F.

Modular setup for freezing meat and fish, the model: $\quad$ Ty 3644-001-86165785-2010. Date of implementation 08.09.2010.
Abramov A.F.
Korobitzyn R.I.

Buslaev I.G.

Abramov A.F.

Buslaev I.G.

Abramov A.F. MY3-07-10 


\section{REFERENCES}

[1] Abramov, A.F. (2000) Natural cold in the North-A key source of energy-saving technologies. Proceedings of the International Forum on Science, Technology and Education, т. 2, Moscow, Russia, 112-113.

[2] Abramov, A.F. and Pavlova, A.I. (2005) Production of frozen horse milk. In: Abramov, A.F. and Pavlova, A.I. Eds., The Russian Academy of Agricultural Sciences, Siberian Branch, The Yakut Scientific Research Institute of Agriculture, Yakutsk, 32.

[3] Abramov, A.F. (2007) The use of natural cold in the processing and storage of food. Journal of Science and Technology in Yakutia, Novosibirsk, 112-124.

[4] Abramov, A.F. (2010) Natural cold-The main reserve of energy-saving technology for the processing and storage of food in the Far North. Proceedings of the 7th International Conference of Food, Environment, Quality, Krasnoobsk, Russia, 21-22 November 2010, 11-12.

[5] Climate of the Yakut ASSR (1968) Atlas, Leningrad, 32. 